\title{
Reuse of Ablution Water to Improve Peat Soil Characteristics for Ornamental Landscape Plants Cultivation
}

\author{
Radin Maya Saphira Radin Mohamed ${ }^{*}, 1$, Al-Gheethi AA ${ }^{1}$, Junita Abdul Rahman ${ }^{1}$, Amir \\ Hashim Mohd Kassim ${ }^{1}$ and Sabariah Musa ${ }^{1}$ \\ ${ }^{1}$ Micro-pollution Research Centre (MPRC), Department of Water and Environmental Engineering, \\ Faculty of Civil \& Environmental Engineering, Universiti Tun Hussein Onn Malaysia, 86400 Parit \\ Raja, Batu Pahat, Johor, Malaysia
}

\begin{abstract}
The present study aimed to reuse of ablution water for washing peat soil in order to reduce the concentrations of heavy metals in these soils which might effect negatively on the plant growth. The washing process design was similar to horizontal subsurface flow constructed wetlands (HSSFCW) consist of layers of peat and sand soil and surrounded by gravel on both sides. Strelitzia sp. was used to detect the presence negative effect of the washing process on the morphological characteristics of the plants. The physical and chemical characteristics of ablution water was examined before and after the washing process by using Inductively Couple Plasma- Mass Spectrometer (ICP-MS) Atomic Absorption Spectrometer (AAS). The characteristics of peat soil before and after the washing process were examined by using X-Ray Fluorescence (XRF). The results revealed that the percentage of $\mathrm{FeO}_{3}$ in peat soil reduced from 45.80 to $1.01 \%$. The percentage of $\mathrm{SiO}_{2}$ in sand soil dropped from 87.7 to $67.10 \%$. Parameters of ablution water resulted from the washing process which including Biological Oxygen Demand $\left(\mathrm{BOD}_{5}\right)$ and heavy metals have increased but still within the standard limits for the disposal of ablution water into the environment. No atrophy was observed in Strelitzia sp. leaves, indicating the ability of plant to grow normally. It can be concluded that the utilization of ablution water in the washing of peat soil has improve the characteristics of the soil without effect on their organic constitutes.
\end{abstract}

\section{Introduction}

Peat soil is a class of soils which has between 50 and $75 \%$ of organic matter and formed in natural environments due to the slow decay of materials [1]. It represent $8 \%$ of the total area (about 3 million hectares) in Malaysia [2].Peat is considered as problematic soils in the view of design parameter by the geotechnical engineers because its engineering characteristic are inferior to those of the other soft soils which make it unsuitable for

\footnotetext{
* Corresponding author: maya@uthm.edu.my
} 
construction in its natural stage. Peats are found to contain high organic matter and are generally associated with poor strength characteristics, large deformation, high compressibility, and high magnitude and rates of creep [3].

Constitutes of peat soil which including dissolved nutrients and organic matter as well as macro-elements are more benefit for the plant growth. However, the high concentrations of organic matter is associated with the lowering in $\mathrm{pH}$ values to less than $\mathrm{pH} 4$ which might affect negatively on the plant growth and crop production. Moreover, the high concentration of inorganic matter such as presence of heavy metals might lead to be accumulated in the plant tissue and then transmitted into animal and human. Peat soil has a $\mathrm{pH}$ ranged from $\mathrm{pH} 3.5$ to 5 [4], in which the toxicity of heavy metal become more effect on the plant growth. For instance, nickel ions with 0.5 to $1 \mathrm{mg} \mathrm{L}^{-1}$ of concentrations are toxic to a number of plants at. However, the toxicity it reduced at neutral or alkaline $\mathrm{pH}$ [5].The forest trees has a potential to grow at low $\mathrm{pH}$ values, but most of crop and ornamental plants grow best with optimum $\mathrm{pH}$ between $\mathrm{pH} 5.5$ and 7.5. The adjustment of soil $\mathrm{pH}$ might be carried out by using lime which lead to increase the $\mathrm{pH}$ to alkaline values [6]. Nonetheless, the main chelating of peat soil lies in the presence of heavy metals which are not reduced by using the lime. In order to reduce the metal ions, some authors suggested to use phytoremediation process in which a heavy metal tolerant plant species are applied for cleaning polluted soils $[7,8]$, but this technique take long time depend on the generation time of the plants. Other authors have investigated washing of metal contaminated garden soil using EDTA $[9,10]$. However, the utilization of chemical treatment of soil might associated with secondary productions with adverse effect on the soil characteristics. The safe method for washing of contaminated soil might be by using water. So far, the high expensive for water resource limit the utilization of this technique. Moreover, the ablution water might represent an alternative source of water used for the washing process. The water quality parameters of ablution water including Biological Oxygen Demand (BOD), Chemical Oxygen Demand (COD) and are within the standards limits of Environmental Quality Act 1974for the disposal, and thus it is usually flowed directly to the drain. Hence, these wastes might be used with an efficient for the peat soil washing and this is the focus of the current work which aimed to examine a design similar in the structure to the horizontal subsurface flow constructed wetlands (HSSFCW) and consisted of two layers including peat and sand soil and surrounded by gravel on both sides. This design will be used for cultivation of ornamental landscape plants which can be used in parks and public gardens as well as on the sides of public roads. The characteristics of peat soil which included heavy metals and acidity will be improved by the washing process using ablution water to be more applicable for the cultivation purpose and this emphasize the novelty of the work.

\section{Materials and methods}

\subsection{Sampling}

Peat soil were collected from Parit Raja, Johor Malaysia and then placed in a structure similar to HSSFCW design with $36 \times 22 \times 23 \mathrm{~cm}$ of size and mixed with the sand soil. The ablution water $(10 \mathrm{~L})$ were collected from UTHM Mosque and then transported into the laboratory. The physical and chemical characteristics of the ablution water were determined according to APHA [11] and then stored in a storage tank until the utilization for the washing process. 


\subsection{Peat soil washing system}

In order to wash peat soil, one layer of peat soil and two layers of sand soil were placed in horizontal form HSSFCW (Fig. 1). The volume of the container used for HSSFCW was $541.10 \mathrm{~cm}^{3}$ fill-up with $8.125 \mathrm{~kg}$ of peat $(2.708 \mathrm{~kg})$ and sand soil $(5.416 \mathrm{~kg})$. Two HSSFCW container were used one without plant (Reactor A) (Fig. 1) and the second one with plant (Reactor B) (Fig. 2). Reactor B with Strelitziasp. was used to detect the presence or absence negative effect of the washing process on the morphological characteristics of the plants. The ablution water was pumped from the storage tank through the layers with fixed flow rate $(4.22 \mathrm{~mL} / \mathrm{min})$ and the infiltration process conducted for 5 days. The flowrate and HRT used here was adjusted to be more appropriate to be used in the filed study. Reactor B has similar function to Reactor A, but as a result for using Strelitziasp. the reactor B was supported on both side with gravel to be more appropriate to cultivate of Strelitziasp.

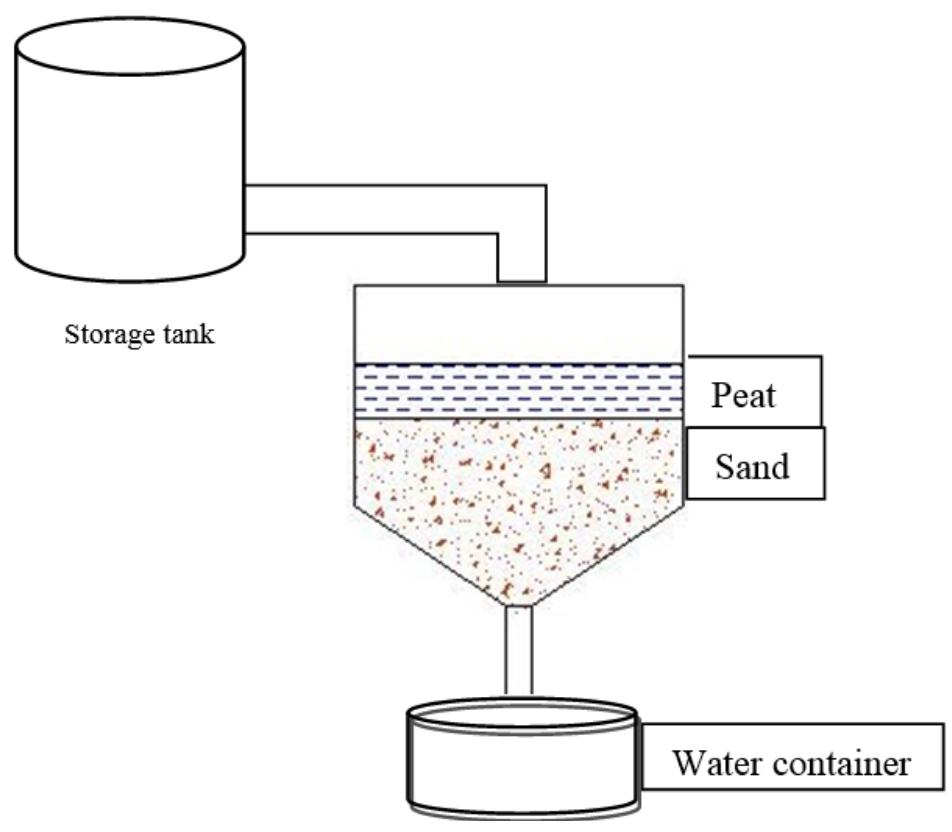

Fig. 1. Reactor A, washing system unit 


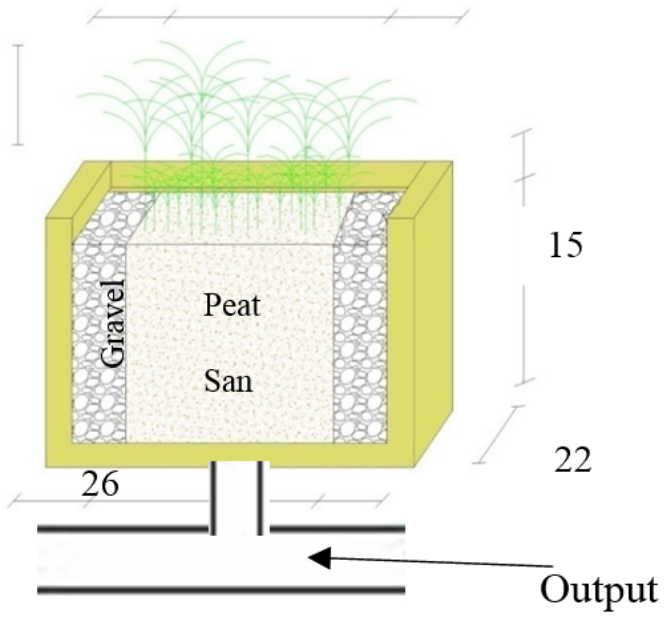

Fig. 2. Schematic diagram of Reactor B

\subsection{Analytical methods}

The characteristics of influent and effluent of $\mathrm{HSSFCW}$ including, $\mathrm{BOD}_{5}$, turbidity, electrical conductivity (EC), $\mathrm{pH}$, sodium adsorption ratio (SAR), sodium $\left(\mathrm{Na}^{+}\right)$, chloride $\left(\mathrm{Cl}^{-}\right)$, total coliform (TC) were conducted according to APHA (2005). The heavy metals and trace elements concentrations including cadmium $(\mathrm{Cd})$, chromium $(\mathrm{Cr})$, copper $(\mathrm{Cu})$, manganese $(\mathrm{Mn})$ and zinc $(\mathrm{Zn})$ were carried out by using Inductively Couple Plasma- Mass Spectrometer (ICP-MS) while Iron (Fe) and magnesium $(\mathrm{Mg})$ were determined by using Atomic Absorption Spectrometer (AAS) according to APHA [11]. These parameters were tested on 3,4 and $5^{\text {th }}$ day of the washing process. The characteristics of peat soil before and after the washing process were examined by using X-Ray Fluorescence (XRF).

\section{Results and discussions}

The characteristics of peat soil before and after washing process conducted using X-Ray Fluorescence technique revealed that the peat soil has higher concentrations of $\mathrm{Fe}_{2} \mathrm{O}_{3}$ and $\mathrm{K}_{2} \mathrm{O}$ than the sand soil, in contrast, sand soil has higher concentrations of $\mathrm{SiO}_{2}$ than peat soil (Table 1). Other heavy metals found in peat soil included $\mathrm{Al}_{2} \mathrm{O}_{3}(7.88 \%), \mathrm{ZnO}(6.03 \%)$, $\mathrm{K}_{2} \mathrm{O}(5.15 \%), \mathrm{MgO}(0.59 \%)$, and $\mathrm{MnO}(0.13 \%)$. The presence of $\mathrm{SiO}_{2}(22.30 \%)$ in peat soil indicate to that the peat soil contains detectable amounts of sand soils. 
Table 1. Chemical composition in peat and sand soil before and after washing process

\begin{tabular}{|c|c|c|c|c|}
\hline \multirow{2}{*}{ Formula } & \multicolumn{2}{|c|}{ Before washing } & \multicolumn{2}{c|}{ After washing } \\
\cline { 2 - 5 } & Peat (\%) & Sand (\%) & Reactor A (\%) & Reactor B (\%) \\
\hline $\mathrm{CO}_{2}$ & 0.10 & 0.10 & 0.10 & 0.10 \\
\hline $\mathrm{Fe}_{2} \mathrm{O}_{3}$ & 45.80 & 0.44 & 1.01 & 0.80 \\
\hline $\mathrm{SiO}_{2}$ & 22.30 & 87.70 & 67.10 & 70.90 \\
\hline $\mathrm{Al}_{2} \mathrm{O}_{3}$ & 7.88 & 10.80 & 7.32 & 7.50 \\
\hline $\mathrm{ZnO}$ & 6.03 & $<\mathrm{DL}$ & $<\mathrm{DL}$ & $<\mathrm{DL}$ \\
\hline $\mathrm{K}_{2} \mathrm{O}$ & 5.15 & 0.27 & 0.47 & 0.38 \\
\hline $\mathrm{SO}_{3}$ & 5.12 & $<\mathrm{DL}$ & 0.69 & 0.68 \\
\hline $\mathrm{CaO}$ & 4.87 & $<\mathrm{DL}$ & 1.21 & 0.56 \\
\hline $\mathrm{Cl}$ & 0.85 & $<\mathrm{DL}$ & 0.14 & 0.16 \\
\hline $\mathrm{P}_{2} \mathrm{O}_{5}$ & 0.76 & $<\mathrm{DL}$ & $<\mathrm{DL}$ & $<\mathrm{DL}$ \\
\hline $\mathrm{MgO}$ & 0.59 & $<\mathrm{DL}$ & $<\mathrm{DL}$ & $<\mathrm{DL}$ \\
\hline $\mathrm{TiO}$ & 0.30 & 0.35 & 0.51 & 0.52 \\
\hline $\mathrm{Br}$ & 0.17 & $<\mathrm{DL}$ & $<\mathrm{DL}$ & $<\mathrm{DL}$ \\
\hline $\mathrm{MnO}$ & 0.13 & $<\mathrm{DL}$ & $<\mathrm{DL}$ & $<\mathrm{DL}$ \\
\hline
\end{tabular}

*DL(Detection limits)

The washing system conducted in this study exhibited high efficiency in the reduction of the parameters of the peat soil.The composition of peat soils have changed significantly after the washing process. The percentage of $\mathrm{FeO}_{3}$ in peat soil reduced from 45.80 to 1.01 and $0.8 \%$ in reactor $\mathrm{A}$ and $\mathrm{B}$, respectively.The concentrations of $\mathrm{K}_{2} \mathrm{O}, \mathrm{SO}_{3}, \mathrm{CaO}, \mathrm{Cl}$, decreased significantly, $\mathrm{ZnO}, \mathrm{P}_{2} \mathrm{O}_{5}, \mathrm{MgO}, \mathrm{Br}$ and $\mathrm{MnO}$ reduced to less than the detection limits. These findings confirm that the potential of ablution water to improve of peat soils. Some of heavy metals in the soil are necessary for plant growth because they acts as a trace elements and cofactors for several enzymes. For instance, $\mathrm{Zn}^{2+}$ is a cofactor in some essential enzymes in animals and plants, $\mathrm{Cu}^{2+}$ is an important metal for many biological functions, but at 0.1 to $1.0 \mathrm{mg} \mathrm{L}^{-1}$ is toxic to a number of plants [5]. Nonetheless, some of metals are toxics $\mathrm{Pb}^{2+}$ is a toxic element, and no useful biological function of lead has been reported $[12,13,14,15]$. Akrivos et al. [16] indicated that zinc $\left(\mathrm{Zn}^{2+}\right)$, copper $\left(\mathrm{Cu}^{2+}\right)$, nickel $\left(\mathrm{Ni}^{2+}\right)$ and chromium $\left(\mathrm{Cr}^{3+}\right)$ effects on plant growth and crop yields and are known to be cumulative toxins, while lead $\left(\mathrm{Pb}^{2+}\right)$, cadmium $\left(\mathrm{Cd}^{2+}\right)$ and mercury $\left(\mathrm{Hg}^{2+}\right)$ are toxic to the animal or human digest of the plants and might be mutagen causing cancer [17]. Hence, the reduction of the metal ions in the peat soil might limit the health risk. The health risk associated with the heavy metals lie in their accumulation in the human bodies and form strong toxic complexes which makes them too dangerous for any physiological function [12].

In order to confirm the reduction in parameters of peat soil, the characteristics of ablution water before and after the washing process were determined (Table 2). It can be noted that the parameters of these water have changed significantly. The concentrations of $\mathrm{BOD}_{5}$ increased from $2 \mathrm{mg} \mathrm{L}^{-1}$ to $6.5 \mathrm{mg} \mathrm{L}^{-1}$ after 5 days of the washing process of peat soil. $\mathrm{pH}$ of the water has decreased from 8.65 to 5.4 , indicating to migration proton ions from the peat soil to the ablution water. However, the concentrations of $\mathrm{BOD}_{5}$ in the output water was not high and still within the standards limits of wastewater discharge. 
Table 2. Chemical and physical parameters of ablution water before and after the utilization in the washing process of the peat soil

\begin{tabular}{|c|c|c|c|c|}
\hline \multirow{2}{*}{ Parameter } & \multirow{2}{*}{$\begin{array}{c}\text { Input ablution } \\
\text { water }\end{array}$} & \multicolumn{3}{|c|}{ Output ablution water } \\
\cline { 3 - 5 } & & $\mathbf{3}$ days & 4 days & $\mathbf{5}$ days \\
\hline BOD $_{5}$ & $2 \mathrm{mg} / \mathrm{L}$ & $4.7 \mathrm{mg} / \mathrm{L}$ & $6.1 \mathrm{mg} / \mathrm{L}$ & $6.5 \mathrm{mg} / \mathrm{L}$ \\
\hline Turbidity & $7 \mathrm{NTU}$ & $13 \mathrm{NTU}$ & $14 \mathrm{NTU}$ & $17 \mathrm{NTU}$ \\
\hline $\mathbf{p H}$ & 8.65 & 5.5 & 5.46 & 5.4 \\
\hline SAR & $0.46 \mathrm{meq} / \mathrm{L}$ & $0.48 \mathrm{meq} / \mathrm{L}$ & $0.60 \mathrm{meq} / \mathrm{L}$ & $0.69 \mathrm{meq} / \mathrm{L}$ \\
\hline Cl & $16.40 \mathrm{mg} / \mathrm{L}$ & $19.44 \mathrm{mg} / \mathrm{L}$ & $19.85 \mathrm{mg} / \mathrm{L}$ & $20.02 \mathrm{mg} / \mathrm{L}$ \\
\hline EC & $38.1 \mu \mathrm{S} / \mathrm{cm}$ & $42.4 \mu \mathrm{S} / \mathrm{cm}$ & $48.5 \mu \mathrm{SS} / \mathrm{cm}$ & $49.2 \mu \mathrm{S} / \mathrm{cm}$ \\
\hline E. coli & $27 \mathrm{CFU} /$ & $82 \mathrm{CFU} / 100 \mathrm{~mL}$ & $96 \mathrm{CFU} / 100 \mathrm{~mL}$ & $115 \mathrm{CFU} / 100 \mathrm{~mL}$ \\
& $100 \mathrm{~mL}$ & & & \\
\cline { 3 - 5 } & & &
\end{tabular}

SAR (Sodium adsorption ratio), Biological Oxygen Demand (BOD), Chlorine (Cl), Electrical Conductivity (EC).

Sodium adsorption ratio (SAR) indicate to the concentrations of solids dissolved in the soil which including $\mathrm{Na}, \mathrm{Ca}$ and $\mathrm{Mg}$, presence of high concentrations for these metals decrease the ability of soil to form stable aggregates and loss of the soil structure. Besides, this situation lead to reduce the permeability and infiltration of the soil to infiltrate water for crop production. However, these metal play important role as micronutrient and macronutrient for the plant growth. $\mathrm{Ca}^{2+}$ ions are necessary to transport other nutrient in the plant and magnesium is needed for photosynthesis process [18]. $\mathrm{Mg}^{2+}$ is an essential element in biological systems because it is present in every cell type in every organism [19]. Moreover, Magnesium nutrient needed in plant with concentrations between 6 and $12 \%$ [20]. In washing process conducted in this study has reduced the SAR concentrations to be within the range required for plant growth. The high level of $\mathrm{Cl}$ in soil might deteriorate the soil properties and affect yields of different crops [21].

The results for concentrations of heavy metals in the ablution water revealed that some metal ion concentrations increased in the output ablution water at 3 Day HRT and then decreased at 5 Day HRT, while others were varied during the washing process period (Table 3). These variation might be related to the nature of heavy metals in the soil as free ions in the water contents or bounded to the organic matter. The concentrations of $\mathrm{Cd}^{2+}$ increased from $0.23 \mathrm{ppb}$ in the ablution water used to $0.4 \mathrm{ppb}$ at 3 Day HRT, and then reduced to $0.04 \mathrm{ppb}$ at 5 Day HRT. Similar findings were recorded for $\mathrm{Cr}$ and $\mathrm{Zn}$. These results revealed that the washing process of the peat soil with the ablution water was efficient in reduce of these metals to the minimum concentrations. $\mathrm{Cd}$ and $\mathrm{Cr}$ are a toxic elements, therefore, the reduction of these metal from the soil might support the plant growth. The concentrations of $\mathrm{Cu}$ and $\mathrm{Mn}$ increased at 3 Day HRT, and then decreased at 4 Day HRT, thereafter increased again at 5 Day HRT, these variations might be due to the degradation process which take place in the peat soil as a results of microbial activities. The degradation process lead to release some bounded metals on the organic compound into the surrounded medium. 
Table 3. Heavy metals concentrations in the ablution water before and after utilization in the washing process

\begin{tabular}{|c|c|c|c|c|c|c|}
\hline \multirow{3}{*}{$\begin{array}{c}\text { Metal } \\
\text { ions }\end{array}$} & \multicolumn{6}{|c|}{ Metal ion concentration (ppb) } \\
\hline & \multicolumn{2}{|c|}{3 Day HRT } & \multicolumn{2}{|c|}{4 Day HRT } & \multicolumn{2}{|c|}{5 Day HRT } \\
\hline & $\begin{array}{l}\text { Input } \\
\text { ablution } \\
\text { water }\end{array}$ & $\begin{array}{l}\text { Output } \\
\text { ablution } \\
\text { water }\end{array}$ & $\begin{array}{l}\text { Input } \\
\text { ablution } \\
\text { water }\end{array}$ & $\begin{array}{l}\text { Output } \\
\text { ablution } \\
\text { water }\end{array}$ & $\begin{array}{l}\text { Input } \\
\text { ablution } \\
\text { water } \\
\end{array}$ & $\begin{array}{l}\text { Output } \\
\text { ablution } \\
\text { water }\end{array}$ \\
\hline $\mathrm{Cd}$ & 0.231 & 0.401 & 0.131 & 0.214 & 0.021 & 0.045 \\
\hline $\mathrm{Cr}$ & 2.319 & 2.586 & 2.772 & 1.984 & 0.887 & 0.766 \\
\hline $\mathrm{Cu}$ & 15.591 & 14.663 & 3.601 & 11.878 & 11.667 & 37.469 \\
\hline $\mathrm{Mn}$ & 2.783 & 44.031 & 5.328 & 4.947 & 2.972 & 15.102 \\
\hline $\mathrm{Zn}$ & 10.569 & 33.187 & 6.166 & 8.422 & 12.806 & 8.331 \\
\hline $\mathrm{Fe}$ & 0.040 & 0.223 & 0.051 & 0.346 & 0.046 & 0.297 \\
\hline $\mathrm{Mg}$ & 0.927 & 0.838 & 0.878 & 0.786 & 0.860 & 0.840 \\
\hline
\end{tabular}

The morphological characteristics of Strelitziasp. indicated that it's grow normally no more changes in their morphology. The leaves were between 30 and $200 \mathrm{~cm}$ long and between 10 and $80 \mathrm{~cm}$ broad. No atrophy was observed in the plant leaves, indicating the ability of plant to grow normally. Moreover, the Strelitziasp. plant was suitable to be planted in the soil $\mathrm{pH}$ in range of 5 to 7 . It has to mention that the current work might provide an alternative method to cultivation of ornamental landscape plant. By applying the peat soil and ablution water, no more fertilizers are required because the peat soil is very rich with the organic matters and elements necessary for plant growth. The ablution water would be used to irrigate the plants during the dry season, therefore, it will be an alternative for the storm water. The application of ablution water for the irrigation would lead to reduce the heavy metal load.

\section{Conclusion}

The findings in the present work revealed the efficiency of ablution water in the washing of peat soil and reduction the concentrations of heavy metals. The utilization of ablution water in the washing of peat soil might is an alternative methods for chemical and biological techniques. The ablution water has dual role for reduction of heavy metals contents and irrigation process. More critical analysis including the field scale experiments might provide more details on the efficiency this study.

The authors gratefully acknowledge Ministry of Higher Education of Malaysia for the research project financial support under fundamental research grant scheme (FRGS) vot No. 1574 and prototype research grant scheme (PRGS) vot G004.

\section{References}

[1] B. Kalantari, A. Prasad, A. Study of the effect of various curing techniques on the strength of stabilized peat. Transportation Geotechnics, 1 (3), 119-128, (2014)

[2] B. K. Huat, Organic and Peat Soils Engineering. Serdang, University Putra Malaysia, Malaysia, (2004)

[3] S. Kazemian, A. Prasad, B. B. Huat, M. Barghchi, A.State of art review of peat: Geotechnical engineering perspective. Int. J. Phys. Sci., 6(8), 1974-1981, (2011) 
[4] J. Abd Rahman, C. M. Chan, A preliminary study of the threshold limit for cementation of peat at different decomposition levels. Zaytoonah University Int. Engineering Conf. on Design and Innovation in Sustainability 2014 (ZEC Infrastructure 2014). Amman, Jordan, (2014)

[5] FAO, Irrigation in the Middle East region in figures. Aquastat Survey. Edited by Frenken, K. Land and Water Division. Food and Agriculture Organization. FAO Water Reports 34, (2008)

[6] N. P. Anderson, J. M. Hart, D. M. Sullivan, D. A Horneck, G. J. Pirelli, N. W. Christensen, Applying lime to raise soil $\mathrm{pH}$ for crop production (western Oregon). Corvallis, Or.: Extension Service, Oregon State University, (2013)

[7] A.L. Salido, K.L. Hastly, J.M. Lim, D.J Butcher, Phytoremediation of arsenic and lead in contaminated soils using Chinese brake ferns (Pterisvittata) and Indian mustard (Brassica juncea). Int. J. Phytoremed., 5(2), 89-103, (2003)

[8] M. I. Lone, Z. L. He, P. J. Stoffella, X. E. Yang, Phytoremediation of heavy metal polluted soils and water: progresses and perspectives. J. Zhejiang Univ. Sci. B, 9(3), 210-220, (2008)

[9] D.Voglar, D. Lestan, Pilot-scale washing of metal contaminated garden soil using EDTA. J. Hazard. Mat., 215, 32-39, (2012)

[10]D.,Voglar, D. Lestan, Chelant soil-washing technology for metal-contaminated soil.Environ. Technol., 35(11), 1389-1400, (2014)

[11]APHA, American Public Health Association, Inc. Standard methods for the examination of water and wastewater (21st Ed.). New York. USA, (2005)

[12]A.A. Al-Gheethi, I. Norli, J. Lalung, T. Azieda, M. O. Ab. Kadir, Reduction of faecal indicators and elimination of pathogens from sewage treated effluents by heat treatment. Casp. J. Appl. Sci. Res., 2 (2): 29-45, (2013)

[13]Al-Gheethi, A.A., Lalung, J., Efaq, A.N., Bala, J.D.,Norli, I. Removal of heavy metals and $\beta$-lactam antibiotics from sewage treated effluent by bacteria. Clean Technol. Environ Policy, 17 (8), 2101-2123, (2015)

[14]N.M. Jais, Mohamed R.M.S.R., A.A. Al-Gheethi, H.M. Amir, Dual role of phycoremediation of wet market wastewater for nutrients and heavy metals removal and microalgae biomass production. Clean Technol Environ Policy. (2016)

[15] Adel A.S. Banana, R.M.S Mohamed, A. A. S. Al-Gheethi, Mercury pollution for marine environment at Farwa Island, Libya. J. of Environ. Health Sci. Eng., 14(5), (2016)

[16]J. Akrivos, D. Mamais, K. Katsara, A.D. Andreadakis, Agricultural utilization of lime treated sewage sludge. J. Water Sci. Technol., 42,203-210 (2000)

[17]Z.L. He., Yang, X.E. Stoffella, P.J. Trace elements in agroecosystems and impacts on the environment. J. Trace Elements in Med. Biol., 19, 125-140 (2005)

[18]Barker, Allen V., and David J. Pilbeam, eds.Handbook of plant nutrition. CRC press, (2015)

[19] J. E. Lusk, Williams, R. J. P., Kennedy, E. P. Magnesium and the growth of Escherichia coli. J. Biol. Chem., 243(10), 2618-2624 (1968)

[20] Graham, Ellis R. Explanation of theory and methods of soil testing. (1959)

[21]B. B. Huat, Kazemian, S., Prasad, A.,Barghchi, M. State of an art review of peat: General perspective. Int. J.Phy. Sci., 6(8), 1988-1996 (2011) 